\title{
Stimulating Knowledge Sharing by Error Management and Leader-Member Exchange: Psychological Safety as a Mediator
}

\author{
Peter T. van den Berg ${ }^{1}$ \\ Tilburg University, The Netherlands
}

\begin{abstract}
The present study investigated how knowledge sharing within teams is related to employees' perceptions of the work environment. Questionnaires measuring error management, leadermember exchange (LMX), psychological safety, and knowledge sharing were administered to 159 Dutch and Romanian employees from 51 teams in 8 organizations. Hierarchical regression analysis showed that error management and LMX were significantly related to knowledge sharing and that these relationships were mediated by psychological safety. The results for the Dutch and the Romanian samples were not significantly different. It was concluded that, to stimulate knowledge sharing, managers should create safety feelings within teams by being more lenient when subordinates make errors and by building trustful relationships with their subordinates.
\end{abstract}

Keywords: knowledge sharing, psychological safety, error management, leader-member exchange

\section{Résumé}

La présente étude a examiné comment le partage des connaissances au sein des équipes est relié aux perceptions des employés de l'environnement de travail. Des questionnaires qui mesurent le management des erreurs, échange manager-membre (LMX), sécurité psychologique et le partage des connaissances, ont été distribués à 159 employés néerlandais et roumains des 51 équipes dans huit organisations. Une analyse de régression hiérarchique a montré que la gestion des erreurs et LMX était significativement reliée au partage des connaissances et que ces relations ont été véhiculées par la sécurité psychologique. Les résultats pour les échantillons néerlandais et roumains n'étaient pas significativement différents. Il a été conclu que, afin de stimuler le partage des connaissances, les managers doivent créer des sentiments de sécurité au sein des équipes en étant plus clémentes lorsque les subordonnés font des erreurs, et en construisant des relations de confiance avec leurs subordonnés.

Mots-clés: partage des connaissances, sécurité psychologique, management des erreurs, échange manager-membre

\section{Rezumat}

Studiul de faţă a investigat măsura în care împărtăşirea de cunoştinţe în cadrul echipelor este relaţionată cu percepţiile angajaţilor cu privire la mediul de muncă. Chestionare care măsoară managementul erorilor, schimbul lider - membru (LMX), siguranţa psihologică şi împărtăşirea de cunoştinţe au fost administrate la 159 de angajaţi români şi olandezi din 51 de echipe în 8 organizaţii. Analiza de regresie ierarhică a arătat că managementul erorilor şi LMX sunt semnificativ relaţionate cu împărtăşirea de cunoştinţe şi că aceste relaţii sunt mediate de siguranţa psihologică. Rezultatele pentru eşantionul din România şi cel din Olanda nu au fost semnificativ diferite. Studiul concluzionează că, pentru a stimula împărtăşirea de informaţii, managerii ar trebui să creeze un climat de siguranţă în cadrul echipelor, să fie mai îngăduitori când apar erori şi să construiască relaţii de încredere cu angajaţii lor.

Cuvinte cheie: împărtăşirea de cunoştinţe, managementul erorilor, schimbul lider - membru, siguranţa psihologică

\footnotetext{
${ }^{1}$ Adresa de corespondenţă: p.t.vandenberg@uvt.nl
} 


\section{Introduction}

Knowledge represents a critical resource for organizations and numerous studies have demonstrated benefits for teams that engage in knowledge sharing within the work group (Staples \& Webster, 2008; Argote \& Ingram, 2000). Knowledge sharing has been linked with increased adaptive learning (Tolbert \& Hall, 2009), organizational effectiveness (Argote \& Ingram, 2000), and creative ideas (Paulus \& Yang, 2000). Connelly and Kelloway (2003) have distinguished between knowledge sharing and information sharing. Whereas information sharing can be unidirectional and unrequested, knowledge sharing contains an element of reciprocity. They have defined knowledge sharing as: " a set of behaviors that involve the exchange of information with or assistance to others” (p. 294). Bakker, Leenders, Gabbay, Kratzer, and Van Engelen (2006) have made a further distinction between exploitation and exploration as forms of knowledge sharing. The current study focuses on the exploration of knowledge sharing which involves processes whereby knowledge is shared, synthesized, and new knowledge is created. Knowledge sharing within a team enables its members to combine current knowledge with new information in order to develop creative ideas.

Transactive memory theory states that a team has a shared memory system for coordinating knowledge within the team (Wegner, 1987; Kozlowski \& Ilgen, 2006). Knowledge is exchanged through team processing techniques such as encoding, storing, and retrieving, thereby connecting the memory systems of the members (Oshri, Van Fenema, \& Kotlarski, 2008). The keyword here is interpretation. People receive data and information from their work environment and knowledge is created through interpretation (Bakker, Leenders, Gabbay, Kratzer, \& Van Engelen, 2006). Knowledge sharing helps individuals view topics from a different or new perspective, discover new relationships, and form new combinations from old concepts, thus, building creativity.

However, knowledge sharing has not been easy to create within a team (Argote, Ingram, Levine, \& Moreland, 2000). Therefore, it is important to know how knowledge sharing among team members can be stimulated. Social exchange theory presumes that employees feel safe when a) they are not punished for making honest mistakes, and b) there is trust between the leader and the subordinates (Argote et al., 2000). And when employees feel safe they will share more knowledge among themselves within the work team. Several studies suggest that in turn psychological safety is affected by error management and leader-member exchange relationship (LMX) (see Edmonson, 2004). Therefore, the research question of the present study is: Are the relationships of error management and LMX with knowledge sharing mediated by psychological safety?

\section{Psychological Safety}

Psychological safety concerns an individual's perceptions of the consequences of taking interpersonal risks in the work environment. It consists of "taken-for-granted beliefs about how others will respond when one puts oneself on the line, such as by asking a question, seeking feedback, reporting a mistake, or proposing a new idea" (Edmondson, 2004, p. 241). In the present study, psychological safety was defined as a belief that the team is safe when taking interpersonal risk and when discussing mistakes or errors (Edmondson, 1999; Baer \& Frese, 2003; Carmeli \& Gittell, 2009).

Social exchange theory has developed over several decades to explain noncontractual interactions between people (Staples \& Webster, 2008). Because there is no way to ensure an appropriate return for a favor, Blau (1964) has noted that one of the underlying conditions of an effective social exchange is trust. The role of trust in the knowledge sharing process, a form of social exchange, has been studied by several researchers. For example, Bakker et al. (2006) found that social capital resided in team membership. Other researchers (e.g. Butler, 1999; Staples \& Webster, 2008) reported that interpersonal trust had a positive effect on knowledge sharing. Because psychological safety involves, and even goes beyond interpersonal trust in that there is a climate of mutual respect (Edmondson, 1999), one can expect that knowledge sharing will be enhanced when teams feel safe. When you feel comfortable in your work team, you are more willing to share your knowledge with your team members. Therefore, psychological safety affects knowledge sharing, which in turn affects the creativity of team members. 


\section{Error Management}

Van Dyck, Frese, Baer, and Sonnentag (2005) have argued that organizations need to manage how they treat employees who have made honest mistakes. These authors defined error management as a management style in which errors are not disapproved and mistakes are handled with considered judgment. Van Dyck et al. (2005) stated that proper error management assumes that human errors can never be completely prevented, and that it is essential to question what can be done when errors do occur. Errors can lead to negative consequences (e.g., waste of time, misunderstandings) as well as positive ones (e.g., learning, creative thinking). The ability to learn from failure has been postulated by several authors as fundamental to adapting (Sitkin, 1996; Starkey, 1998; Cannon \& Edmondson, 2001).

It is presumed in the current research that the relationship between error management and knowledge sharing can be explained in part by the mediating role of psychological safety. The assumption is that employees who perceive a climate of error management are less fearful of making mistakes because they know that honest mistakes will not necessarily be punished. Thus, error management enhances the climate of psychological safety in the team, which in turn improves the level of knowledge sharing among its members. Note that a clear distinction is made between unintentional errors and mistakes as a consequence of thoughtlessness. Therefore, the following hypothesis was formulated:

Hypothesis 1: The relationship between error management and knowledge sharing is mediated by psychological safety.

\section{Leader-Member Exchange Relationship}

How leaders respond to member behaviors and events affects members' perceptions of proper and safe behavior (Edmondson, 2003). The perceptions of a psychologically safe work environment are to a large extent affected by the relationship one has with one's immediate manager (Edmondson, 2003; May, Gilson, \& Harter, 2004). Leaders can create environments that foster exchange of knowledge by acting in ways that promote psychological safety in the team. Within the broad area of leadership research, the leader-member exchange (LMX) relationship distinguishes itself by focusing on the trust within the dyadic relationship between a leader and a member (Gerstner \& Day, 1997). Thus, LMX stresses the mutual and reciprocal quality of the one-on-one relationship between a leader and a team member (Graen \& Uhl-Bien, 1995). The main assumption behind LMX theory is that leaders discriminate among subordinates and treat them differently and accordingly (Dansereau, Graen, \& Haga, 1975; Liden, Wayne, \& Sparrowe, 2000). Leaders establish high quality exchanges with some subordinates and low quality exchanges with others (Liden et al., 2000). Low quality LMX relations can be characterized as purely economic (Blau, 1964) and as a contractual exchange characterized by less loyalty and support (Dienesch \& Liden, 1986). High LMX relations are characterized by high levels of mutual support, trust, and loyalty (Blau, 1964; Graen \& Uhl-Bien, 1995; Liden et al., 2000). A leader in a high quality LMX relation will spend more time working with a subordinate and will value their input more. Dansereau et al. (1975) showed that the latitude displayed by a leader, when a subordinate negotiated his or her role, depended on the behavior of both players. Furthermore, Gerstner and Day's (1997) metaanalysis revealed significant positive correlations between LMX relations and perceived performance, job satisfaction, organizational commitment, role clarity and competence; and negative correlations with turnover intentions. This indicates that LMX has a substantial effect on the performance, behavior, attitudes, and work experiences of the employee.

Liden et al. (2000) enumerated several important factors that characterized high LMX relations, namely, task challenge, decisionmaking, and emotional support. A leadermember relationship that is characterized by these factors, instead of a relationship in which one is controlled by an autocratic boss, should enhance perceptions of safety (Edmondson, 1999) and raise team members' selfdetermination and interest in their work (May et al., 2004). Self-determined individuals feel safe to perform their work according to what is required by the circumstances, to discuss mistakes, and to share knowledge (Edmondson, 1996; 1999). Conversely, members in a low LMX relationship feel unsafe because they perceive their leader as monitoring their work and as being 
disinterested (Graen \& Uhl-Bien, 1995). This leads to the assumption that high LMX relationships will help team members feel safe in their team, whereas low LMX relationships hinder the feelings of psychological safety. Therefore, the following hypothesis was formulated:

Hypothesis 2: The relationship between LMX and knowledge sharing is mediated by psychological safety.

\section{Method}

\section{Participants}

The data were collected from eight organizations in two countries. Eighty-four respondents were from The Netherlands and 75 were from Romania. Organizations in each country were interviewed to gain specific insight into their team structures. The teams were selected because team leaders indicated that knowledge sharing was important issue within the team. The team members participated on a voluntary basis. Paper-andpencil questionnaires were subsequently distributed and respondents were assured that their answers would be treated confidentially. A follow-up email reminder was sent 10 days later which yielded a response rate of $32 \%$.

The sample consisted of fifty-one teams which included a total of 69 males and 90 females. The participants ranged in age from 21 to 63 years $(M=36.15$ years; $S D=$ 10.20). The mean job tenure was 6.27 years (ranging from 0.5 to 33 years; $S D=7.02$ ) and the average team tenure was 2.90 years (ranging from 0.5 to 20 years; $S D=2.84$ ). Groups ranged in size from two to 21 individuals $(M=9.64 ; S D=4.97)$. The number of members that participated in the study ranged from one to $17(M=3.12 ; S D=3.01)$. The teams operated in various economic sectors: Advertising (14\%), public finances $(2 \%)$, training $(2 \%)$, oil $(10 \%)$, software $(2 \%)$, military $(2 \%)$, and scientific research $(69 \%)$.

\section{Measures}

Dutch participants were able to answer in Dutch or English whereas Romanian participants received the questionnaire in Romanian. Back-translation was applied to create reliable and valid translations of the questionnaires.

Error management. Error management was measured with several items taken from a 16-item scale that was developed by Van Dyck et al. (2005). Cronbach's alpha for their scale was .92, which indicates a high internal consistency. However, the high alpha value was due most likely to the high content similarity among the sixteen items. Therefore, items that were almost identical to one another were excluded from the questionnaire used in the current study. For example, the item 'After an error occurred, it is analyzed thoroughly' is similar to the items 'Think it through' and 'Analyze what caused an error'. Therefore, the scale was reduced to 10 items without having any material effect on the internal consistency $(\alpha=.83)$. The answer categories ranged from 1 (does not apply at all) to 5 (applies completely).

Leader member exchange relationship. The LMX7 (Graen \& Uhl-Bien, 1995), as modified by Bezuijen, Van den Berg, Van Dam, \& Thierry (2009), was used to measure the leader-member trust. A sample item is: "How would you characterize your working relationship with your team leader?' Answer categories ranged from 1 (poor) to 5 (very good) and Cronbach's alpha was .88.

Psychological safety. Seven items from Edmondson (1999) measured the extent to which team members felt psychologically safe when taking interpersonal risks, speaking openly, and discussing failures. A sample item is: 'It is safe to take risks on this team'. The answer categories ranged from 1 (does not apply at all) to 5 (applies completely). In the present study, the Cronbach's alpha of this scale was .68.

Knowledge sharing. Four items, drawn from Connelly and Kelloway (2003), were used to measure how much knowledge was being shared within the team. As did Staples and Webster (2008), we excluded the item 'This team is good at using the knowledge/ideas of employees', because the intention was to measure whether knowledge was shared, not if or how it was applied. The answer categories ranged from 1 (does not apply at all) to 5 (applies completely). The internal consistency of the scale was, $\alpha=.88$.

Control variables. Team tenure was included as a control variable because it reflects someone's expertise (Oldham \& Cummings, 1996; Kark \& Carmeli, 2009) which in turn could make employees feel more psychological safe as they work for a longer period of time in a team (Halbesleben \& Rathert, 2008). According to transactive memory theory, team tenure has a positive influence on knowledge sharing (Bakker et al., 
2006). When a team works together for a longer period of time, team members know one another better and know how and where to find expertise. Team size was also used as a control variable. Although there is more opportunity to share knowledge in a larger team (Bakker et al., 2006), it can be argued that interactions with other members decrease when the size of the team becomes too large. I also controlled for age because knowledge will grow with age and older members may share more knowledge. Finally, gender was controlled for because women may feel less safe in knowledge-driven teams.

\section{Data Analysis}

Baron and Kenny (1986) have stipulated that three conditions need to be met when testing for a mediator effect: a) a significant relationship should exist between the independent variable and the dependent variable, b) a significant relationship should exist between the independent variable and the mediator, and c) a significant relationship should exist between the mediator and the dependent variable while holding the independent variable constant. When controlling for the mediator, the relationship between the independent and the dependent variable has to become less strong. In the case of a fully mediating effect, the independent variable will have no significant relationship with the dependent variable when the mediator is added to the analysis. Additionally, Sobel's (1982) test for mediation was used to establish the significance of the indirect effect of the independent variable on the dependent variable.

The analyses were performed at the individual level of employees' perceptions. This was done because several variables such as LMX and some control variables are constructs at the individual level. However, some variables like psychological safety are constructs at the team level. Multi-level analysis was not possible because several teams had too few responding members for this analysis. As a control, the analyses were repeated at the team level.

\section{Results}

Table 1 shows the means, the standard deviations, and the bivariate correlations of the variables. Error management was significantly related to psychological safety $(r=.37 ; p<.001)$ and to knowledge sharing $(r=.31 ; p<.001)$. LMX was also significantly related to psychological safety $(r=.39 ; p<.001)$ and to knowledge sharing $(r=.39 ; p<.001)$. Finally, the correlation between psychological safety and knowledge sharing was high $(r=.72 ; p<.001)$. Factor analysis with the items of psychological safety and knowledge sharing showed that in a 2-factor solution the items loaded highest on the intended factors, but some items had high cross-loadings.

Table 1. Descriptives and Intercorrelations

\begin{tabular}{|c|c|c|c|c|c|c|c|c|c|c|}
\hline Variable & M & $S D$ & 1 & 2 & 3 & 4 & 5 & 6 & 8 & 9 \\
\hline 1. Age & 36.15 & 10.20 & & & & & & & & \\
\hline 2. Gender ( $0=$ male; $1=$ female $)$ & - & - & $-.18^{*}$ & & & & & & & \\
\hline 3. Team tenure & 2.90 & 2.84 & $.37^{* * *}$ & $-.20^{*}$ & & & & & & \\
\hline 4. Team size & 9.64 & 4.97 & -.01 & $.19^{*}$ & -.12 & & & & & \\
\hline 5. Error management & 3.54 & .62 & -.00 & -.02 & $-.18^{*}$ & -.04 & $(.83)$ & & & \\
\hline 6. Leader-member exchange & 3.65 & 1.05 & .06 & -.06 & .01 & -.07 & $.38^{* * *}$ & $(.88)$ & & \\
\hline 8. Psychological safety & 3.65 & .56 & .07 & .07 & -.04 & $-.28^{\star * *}$ & $.37^{\star \star \star}$ & $.39^{\star \star \star}$ & $(.68)$ & \\
\hline 9. Knowledge sharing & 3.73 & .80 & .06 & -.15 & .10 & $-.42^{\star \star \star}$ & $.31^{* \star *}$ & $.39^{\star * *}$ & $.72^{\star \star \star}$ & $(.88)$ \\
\hline
\end{tabular}


Table 2 shows the results of the regression analysis for knowledge sharing. The control variables together explained a significant proportion of variance in knowledge sharing $\left(R^{2}=.28 ; p<.001\right)$. The results showed that team size had a significant negative relationship with knowledge sharing $(\beta=-.23$; $p<.01)$. Country was also significantly related to knowledge sharing $(\beta=-.37 ; p<.001)$ and Romanian participants reported lower levels of knowledge sharing than did the Dutch. In step two, error management and LMX were entered into the regression and increased the percentage of explained variance by $11 \%$ ( $p<$ .001). Both error management and LMX were significantly related to knowledge sharing, $\beta=$
$.22 ; p<.01$ and $\beta=.20 ; p<.01$, respectively. These results showed that the first condition for the hypothesized mediation effects was fulfilled. The third condition for a mediation effect was tested by regressing psychological safety on knowledge sharing. Doing so increased the percentage of variance explained in knowledge sharing $\left(\Delta R^{2}=.22 ; p<\right.$ $.001)$ and showed that psychological safety was strongly related to knowledge sharing $(\beta=$ $.59 ; p<.001)$. Moreover, the beta coefficient for error management and LMX were no longer significant. These results showed that the third condition for the two mediation effects was fulfilled.

Table 2. Results of Multiple Regression Analysis Testing the Mediating Effect of Psychological Safety

\begin{tabular}{|c|c|c|c|c|}
\hline Variable & Step 1 & Step 2 & Step 3 & Step 4 \\
\hline \multicolumn{5}{|l|}{ Control } \\
\hline Country ( $0=$ Netherlands; $1=$ Romania) & $-.37^{* * *}$ & $-.29^{* \star *}$ & -.08 & -.10 \\
\hline Sex & .04 & .02 & -.04 & -.04 \\
\hline Age $(0=$ male; $1=$ female $)$ & -.04 & -.02 & -.09 & -.08 \\
\hline Team tenure & -.05 & .02 & .08 & .08 \\
\hline Team size & $-.23^{\star *}$ & $-.25^{\star *}$ & $-.18^{* *}$ & $-.16^{*}$ \\
\hline \multicolumn{5}{|l|}{ Independent } \\
\hline Error management & & $.22^{\star \star}$ & .06 & .06 \\
\hline Leader-member exchange & & $.20^{* *}$ & .09 & .10 \\
\hline \multicolumn{5}{|l|}{ Mediator } \\
\hline Psychological safety & & & $.59^{* * *}$ & $.57^{* \star *}$ \\
\hline \multicolumn{5}{|l|}{ Interaction } \\
\hline Error management $x$ Country & & & & .03 \\
\hline Leader-member exchange $x$ Country & & & & .05 \\
\hline Psychological safety $x$ Country & & & & -.06 \\
\hline$R^{2}$ & $.28^{* * *}$ & $.39^{* * *}$ & $.61^{* * *}$ & $.62^{* * *}$ \\
\hline$\Delta R^{2}$ & & $.11^{\star \star *}$ & $.22^{\star \star \star}$ & .00 \\
\hline
\end{tabular}

${ }^{*} p<.05 .{ }^{* *} p<.01 .{ }^{* * *} p<.001$.

A regression analysis was performed on psychological safety to test the second condition for mediation, namely that a significant relationship should exist between theindependent variable and the mediator (see Table 3). The result of the first step in the analysis showed that the Romanian participants reported lower levels of psychological safety than did the Dutch $(\beta=$ $.43 ; p<.001)$. Also, team tenure was negatively related to psychological safety $(\beta=-.19 ; p<.05)$. In the second step, the percentage of variance explained in psychological safety increased significantly $\left(\Delta R^{2}=.14 ; p<.001\right)$ and error management and LMX were significantly related to psychological safety, $\beta=.27 ; p<.001$ and $\beta=$ $.18 ; \quad p<.05$, respectively. The second condition for both hypothesized mediation effects was thereby fulfilled. 
Table 3. Results of Multiple Regression Analysis Predicting Psychological Safety

\begin{tabular}{|c|c|c|c|}
\hline Variable & Step 1 & Step 2 & Step 3 \\
\hline \multicolumn{4}{|l|}{ Control } \\
\hline Country ( $0=$ Netherlands; $1=$ Romania) & $-.43^{* * *}$ & $-.35^{\star \star \star}$ & $-.34^{* * *}$ \\
\hline Age & .12 & .09 & .10 \\
\hline Sex $(0=$ male; $1=$ female $)$ & .09 & .10 & .10 \\
\hline Team tenure & $-.19^{*}$ & -.11 & -.09 \\
\hline Team size & -.10 & -.12 & -.13 \\
\hline \multicolumn{4}{|l|}{ Independent } \\
\hline Error management & & $.27^{\star \star *}$ & $.29^{* * *}$ \\
\hline Leader-member exchange & & $.18^{*}$ & $.17^{*}$ \\
\hline \multicolumn{4}{|l|}{ Interaction } \\
\hline Error management x Country & & & -.08 \\
\hline Leader-member exchange $\times$ Country & & & -.03 \\
\hline$R^{2}$ & $.22^{* \star *}$ & $.36^{\star \star *}$ & $.37^{\star * *}$ \\
\hline$\Delta R^{2}$ & & $.14^{\star \star *}$ & .01 \\
\hline
\end{tabular}

The indirect effects were tested using Sobel's test. The results showed that the indirect effects of error management $(z=3.48 ; p<$ $.001)$ and of $\operatorname{LMX}(z=2.35 ; p<.01)$ on knowledge sharing through psychological safety were significant. These results confirmed hypothesis 1 , which stated that the relationship between error management and knowledge sharing is mediated by psychological safety, and confirmed hypothesis 2 which stated that the relationship between LMX and knowledge sharing is mediated by psychological safety.

To examine whether the results differed for the Dutch and the Romanian samples, regression analyses were performed in which the cross-products between country and the independent variables were entered. As shown in Table 2 and 3 , none of the interactions were significant indicating that the results in the two samples did not differ significantly. However, the main effects of country showed that in the present sample the Romanian team members reported less psychological safety and less knowledge sharing than the Dutch team members.

\section{Discussion}

The aim of this study is to study how error management and LMX are related to knowledge sharing, and whether these relationships are mediated by psychological safety. The results show that employees who experience a lenient attitude toward making errors and who have a good relationship with their boss perceive more knowledge sharing within their team. That these relationships are mediated by psychological safety suggests that feeling safe is the key reason why employees are more inclined to share their knowledge within the team. These results are in line with authors who emphasize the importance of psychological safety for enhancing knowledge sharing (e.g. Butler, 1999; Staples \& Webster, 2008).

The results show that feelings of psychological safety and level of knowledge sharing decrease as team size increases. Thus, large teams are not beneficial for psychological safety and knowledge exchange. These results may be explained by the fact that it is difficult to build trustful relationships with many team members and to share your knowledge with all of them.

Furthermore, the Dutch participants report higher levels of knowledge sharing and psychological safety than do the Romanians, but the relationships between country and the other independent variables do not differ significantly across countries. This indicates that the results can be generalized across the two countries. Several authors stress the importance of the context in which teams are embedded (see Klein \& Kozlowski, 2000). The present study shows that the levels of the variables can be dependent on the context, but that the relationships among them may not. 


\section{Theoretical Implications}

The present study provides empirical support for social exchange theory (Homans, 1961; Blau, 1964). According to this theory, feelings of interpersonal trust and mutual respect in a team stimulate social exchange because they reduce the threat of competitive behavior (Blau, 1964). Because of the explicit beliefs of being safe within the team, members are willing to take risks when exchanging knowledge with other members, which in turn enhances the amount of knowledge sharing within a team.

The topics of LMX, error management, psychological safety, and knowledge sharing have been used in group research, but the present study shows how these constructs are related. The results suggest that LMX and error management affect knowledge sharing because positive relationships with a leader who is lenient toward making errors creates a climate in which team members feel safe enough to share their knowledge.

\section{Practical Implications}

The findings of this research have practical relevance for team leaders as well as for the senior management of an organization. The finding that error management is related to psychological safety and subsequent knowledge sharing confirms the notion that handling errors constructively has positive consequences (Sitkin, 1996; Starkey, 1998; Cannon \& Edmondson, 2001). A message of tolerance is sent throughout the organization when subordinates are not necessarily punished for making honest errors, which in turn makes people feel safe. Van Dyck et al. (2005) states that programs that cultivate systematic error management are likely be cost-effective and managerial training interventions show moderate efficacy thus far (Burke \& Day, 1986) .

In addition to the effects of error management, the findings show that the relationship between a leader and member affects perceptions of psychological safety. High LMX relationships are positively related to feelings of safety in a team. Thus, a team leader can contribute to the psychological safety of a team by investing in the one-on-one relationships with subordinates. This affects knowledge sharing in the team, which can then subsequently affect learning and organizational effectiveness (Argote \& Ingram, 2000).

\section{Limitations and Future Research}

First, this study is based on crosssectional data, therefore no conclusions concerning causality can be drawn. Longitudinal or experimental research is needed to test for causal effects. Second, the results presented in the tables are based on individual scores. As a control, the scores were aggregated at the team level and used to perform the same regression analyses as presented. The results were similar, except that error management was no more significantly related to knowledge sharing because of the lower number of cases $(N=51$ teams). A third limitation is that the variables are measured with self-reports, which can cause common method variance. Therefore, future research should also use other data sources such as team leaders' opinions about knowledge sharing.

A suggestion for future research would be to study how psychological safety and knowledge sharing affect objective team performance, for example measures of innovation or sales. Psychological safety and knowledge sharing may be attractive team characteristics, but there is only scarce evidence that they contribute to objective measures of team performance. Finally, it would be interesting to investigate whether the effects of psychological safety vary according to the type of team in which one works, such as temporary, virtual, multidisciplinary, and self-managed teams. It is important to know if the results can be generalized to different contexts. The present study is promising with respect to this.

\section{References}

Argote, L., \& Ingram, P. (2000). Knowledge transfer: A basis for competitive advantage in firms. Organizational Behavior and Human Decision Processes, 32, 150-169.

Argote, L., Ingram, P., Levine, J. M., \& Moreland, R. L. (2000). Organizational learning: Creating, retaining, and transferring knowledge. Boston: Kluwer Academic Publishers.

Baer, M., \& Frese, M. (2003). Innovation is not enough: Climates for initiative and psychological safety, process innovations, and firm performance. Journal of Organizational Behaviour, 24, 45-68. 
Bakker, M., Leenders, R. T. A. J., Gabbay, S. M., Kratzer, J., \& Van Engelen, J. M. L. (2006). Is trust really social capital? Knowledge sharing in product development projects. The Learning Organization, 13, 594-605.

Baron, R. M., \& Kenny, D. A. (1986). The moderator-mediator variable distinction in social psychological research: Conceptual, strategic, and statistical considerations. Journal of Personality and Social Psychology, 51, 1173-1182.

Bezuijen, X., Van den Berg, P. T., Van Dam, K., \& Thierry, H. (2009). Pygmalion and employee learning: The role of leader behaviors. Journal of Management, 35, 1248-1267.

Blau, P. (1964). Exchange and power in social life. New York: Wiley.

Burke, M. J., \& Day, R. R. (1986). A cumulative study of the effectiveness of managerial training. Journal of Applied Psychology, 71, 232-245.

Butler, J. K. (1999). Trust expectations, information sharing, climate of trust, and negotiation effectiveness and efficiency. Group and Organization Management, 24, 217-238.

Cannon, M. D., \& Edmondson, A. C. (2001). Confronting failure: Antecedents and consequences of shared beliefs about failure in organizational work groups. Journal of Organizational Behaviour, 22, 161-177.

Carmeli, A., \& Gittell, J .H. (2009). High-quality relationships, psychological safety, and learning from failures in work organizations. Journal of Organizational Behavior, 30, 709-729.

Connelly, C. E., \& Kelloway, K. (2003). Predictors of employees' perceptions of knowledge sharing cultures. Leadership and Organizational Development Journal, 24, 294-301.

Dansereau, F., Graen, G., \& Haga, W. J. (1975). A vertical dyad approach to leadership within formal organizations. Organizational Behavior and Human Performance, 13, 4678.

Dienesch, R. M., \& Liden, R. C. (1986). Leader/member exchange model of leadership: A critique and further development. Academy of Management Review, 11, 618-634.

Edmondson, A. C. (1996). Learning from mistakes is easier said than done: Group and organizational influences on the detection and correction of human error. Journal of Applied Behavioral Science, 32, 5-32.
Edmondson, A. C. (1999). Psychological safety and learning behaviour in work teams. Administrative Science Quarterly, 44, 350383.

Edmondson, A. C. (2003). Managing the risk of learning: Psychological safety in work teams. In M. A. West, D. Tjosvold, \& K. G. Smith (Eds.), International handbook of organizational teamwork and cooperative working (pp. 255-275). Chichester: Wiley.

Edmondson, A. C. (2004). Psychological safety, trust and learning: A group-level lens. In R. Kramer \& K. Cook (Eds.), Trust and distrust in organizations (pp. 239-272). New York: Russell Sage.

Gerstner, C. R., \& Day, D. V. (1997). Meta-analytic review of leader-member exchange theory: Correlates and construct issues. Journal of Applied Psychology, 82, 827- 844.

Graen, G. B., \& Uhl-Bien, M. (1995). Relationshipbased approach to leadership: Development of leader-member exchange (LMX) theory of leadership over 25 years: Applying a multilevel multi-domain perspective. Leadership Quarterly, 6, 219-247.

Halbesleben, J. R. B., \& Rathert, C. (2008). The role of continuous quality improvement and psychological safety in predicting workarounds. Health Care Management Review, 33, 134-144.

Homans, G. (1961). Social behavior: Its elementary forms. London: Routledge \& Kegan Paul.

Kark, R., \& Carmeli, A. (2009). Alive and creating: The mediating role of vitality and aliveness in the relationship between psychological safety and creative work involvement. Journal of Organizational Behavior, 30, 785-804.

Klein, K. J., \& Kozlowski, S. W. J. (2000). Multilevel theory, research and methods in organizations: Foundations, extensions and new directions. San Francisco: JosseyBass.

Kozlowski, S. W. J., \& Ilgen, D. R. (2006). Enhancing the effectiveness of work groups and teams. Psychological Science in the Public Interest, 7, 77-124.

Liden, R. C., Wayne, S. J., \& Sparrowe, R. T. (2000). An examination of the mediating role of psychological empowerment on the relations between the job, interpersonal relationships, and work outcomes. Journal of Applied Psychology, 85, 407-416.

May, D. R. (2003). Fostering the human spirit at work: Toward an understanding of the influences on employees' experienced 
meaningfulness at work. Unpublished manuscript.

May, D. R., Gilson, R .L., \& Harter, L. M. (2004). The psychological conditions of meaningfulness, safety and availability and the engagement of the human spirit at work. Journal of Occupational and Organizational Psychology, 77, 11-37.Oldham, G. R., \& Cummings, A. (1996). Employee creativity: Personal and contextual factors at work. Academy of Management Journal, 39, 607634.

Oshri, I., Van Fenema, P., \& Kotlarsky, J. (2008). Knowledge transfer in globally distributed teams: The role of transactive memory. Information Systems Journal, 18, 593-616.

Paulus, P. B., \& Yang, H. C. (2000). Idea generation in groups: A basis for creativity in organizations. Organizational Behavior and Human Decision Processes, 82, 76-87.

Sitkin, S. B. (1996). Learning through failure: The strategy of small losses. In M. Cohen \& U. Sproull (Eds.), Organizational Learning (pp. 541-577). Thousand Oaks, CA: Sage.

Sobel, M. E. (1982). Asymptotic confidence intervals for indirect effects in structural equations models. In S. Leinhart (Ed.), Sociological methodology 1982 (pp. 290-312). San Francisco: Jossey-Bass.

Staples, D. S., \& Webster, J. (2008). Exploring the effects of trust, task interdependence and virtualness on knowledge sharing in teams. Information System Journal, 18, 617640.

Starkey, K. (1998). What can we learn from the learning organization? Human Relations, 51, 531-546.

Tolbert, P. S., \& Hall, R. H. (2009). Organizations: Structures, processes, and outcomes. Upper Saddle River, NJ: Pearson/Prentice Hall.

Van Dyck, C., Frese, M., Baer, M., \& Sonnentag, S. (2005). Organizational error management culture and its impact on performance: $A$ two-study replication. Journal of Applied Psychology, 90, 1228-1240.

Wegner, D. M. (1987). Transactive memory: A contemporary analysis of the group mind. In B. Mullen \& G. R. Goethals (Eds.), Theories of group behavior (pp. 185-208). New York:Springer-Verlag. 